\title{
PENGEMBANGAN AGROINDUSTRI GULA KELAPA DI KABUPATEN CILACAP: KAJIAN STRATEGI MARKETING HASIL PERTANIAN
}

\author{
THE AGRICULTURAL DEVELOPMENT OF COCONUT SUGAR IN \\ CILACAP DISTRICT: THE STUDY OF MARKETING STRATEGY OF \\ AGRICULTURAL PRODUCTS
}

\author{
*Nariswari Novi Pudyastuti, Masyhuri, dan Any Suryantini \\ Program Studi Magister Manajemen Agribisnis \\ Submitted: 09-10-2018; Revised: 10-06-2019; Accepted: 10-06-2019
}

\begin{abstract}
Coconut sugar industry as a part of agroindustry has given significances in regional agriculture development. However, it has not yet met the businessman needs because of the lack significant industrial development and marketing efficiency. Therefore, this study aims at identifying both the external and internal factors influencing the marketing development and formulating the alternative marketing strategies for coconut sugar products especially in Jeruklegi and Kawunganten District of Cilacap Regency. This area is chosen based on certain considerations and this study involves 47 respondents. The methods used in this study are instrument test analysis, descriptive analysis to identify the internal and external factors, and SWOT analysis to formulate the alternative strategies for coconut sugar industry development. The result shows that generally there is still lack of human resources quality, and based on validity and reliability tests there are eight internal and ten externals factors influencing the coconut sugar marketing in Cilacap Regency. The industrial position is in cell IV which means in a stable phase, meanwhile, the main alternative strategy that can be applied in coconut sugar marketing development in Cilacap Regency is in quadrant 1 namely the SO (Strengths Opportunities) strategy, which includes optimizing the production capacity, expanding the sale area, and increasing the promotional activities. Other supporting alternative strategies that consist of ST strategies (Strength Threats), WO (Weaknesses Opportunities), and WT (Threats Weaknesses) are increasing the use of production equipment technology, increasing marketing efficiency, increasing the market price knowledge, maintaining product quality, choosing managers to form beneficiary group, cooperating among villages, improving the production cleanliness, looking for funds from cooperatives in other areas for business capital, and establishing the information service center.
\end{abstract}

Keywords: Business development; Coconut sugar industry; Marketing strategy; SWOT analysis.

\begin{abstract}
ABSTRAK
Industri gula kelapa sebagai bagian dari agroindustri telah memberikan signifikansi dalam pengembangan pertanian daerah, tetapi belum dapat memenuhi kebutuhan para pengusaha karena kurangnya pengembangan industri yang signifikan dan efisiensi pemasaran. Oleh karena itu, penelitian ini bertujuan untuk mengidentifikasi faktor-faktor eksternal dan internal yang mempengaruhi pengembangan pemasaran dan merumuskan strategi alternatif pemasaran untuk produk-produk
\end{abstract}

*Corresponding author: nariswarinv9@gmail.com.

Copyright@ 2019 THE AUTHOR(S). This article is distributed under a Creative Commons Attribution-Share Alike 4.0 International license. Jurnal Kawistara is published by the Graduate School of Universitas Gadjah Mada. 
gula kelapa khususnya di Kecamatan Jeruklegi dan Kawunganten Kabupaten Cilacap. Area ini dipilih berdasarkan pertimbangan tertentu dengan melibatkan 47 responden. Metode yang digunakan dalam penelitian ini adalah analisis uji instrumen, analisis deskriptif untuk mengidentifikasi faktor internal dan eksternal, dan analisis SWOT untuk merumuskan alternatif strategi pengembangan industri gula kelapa. Hasil penelitian menunjukkan bahwa secara umum jumlah sumber daya manusia yang berkualitas masih sangat kurang dan berdasarkan uji validitas dan reliabilitas terdapat delapan faktor internal dan sepuluh faktor eksternal yang mempengaruhi pemasaran gula kelapa di Kabupaten Cilacap. Posisi industri terdapat pada sel IV yang berarti dalam fase stabil, sementara itu alternatif strategi utama yang dapat diterapkan dalam pengembangan pemasaran gula kelapa di Kabupaten Cilacap adalah kuadran 1 yaitu strategi SO (Strengths Opportunities), yang terdiri dari mengoptimalkan kapasitas produksi, memperluas area penjualan, dan meningkatkan kegiatan promosi. Alternatif strategi pendukung lainnya yang mencakup strategi ST (Strengths Threats), WO (Weaknesses Opportunities), dan WT (Weaknesses Threats) adalah meningkatkan penggunaan teknologi alat produksi, meningkatkan efisiensi pemasaran, meningkatkan pengetahuan mengenai harga pasar, menjaga kualitas produk, memilih pengurus untuk membentuk kelompok penderes, bekerja sama antardesa, meningkatkan kebersihan produksi, mencari dana dari koperasi di daerah lain untuk modal usaha, dan mendirikan pusat layanan informasi..

Kata Kunci: Analisis SWOT; Industri gula kelapa; Pengembangan usaha; Strategi pemasaran.

\section{PENGANTAR}

Pengembangan daerah khususnya pedesaan tidak lepas dari adanya sektor pertanian karena memiliki peluang untuk terus dimanfaatkan, seperti bertambahnya jumlah penduduk akan menyebabkan naiknya kebutuhan pangan. Peningkatan kebutuhan pangan berkualitas sejalan dengan meningkatnya pendapatan masyarakat. Selain itu pengembangan agroindustri akan berdampak pada pertumbuhan ekonomi daerah karena pendapatan petani yang meningkat diharapkan akan mengurangi adanya ketimpangan pendapatan masyarakat (Syahza, 2012). Tanaman kelapa banyak tumbuh di wilayah Pulau Jawa salah satunya terdapat di Kabupaten Cilacap, sehingga agroindustri gula kelapa banyak dijalankan masyarakat pedesaan dan sebagian besar merupakan usaha utama. Usaha sebagai perajin gula kelapa belum mampu mencukupi kebutuhan dan belum terlihat adanya perkembangan signifikan karena kurangnya efisiensi pemasaran. Hal ini dilihat dari harga yang diterima perajin relatif rendah dan jumlah produksi gula yang tidak meningkat, bahkan mengalami penurunan karena tidak sedikit perajin yang melakukan alih profesi, sedangkan permintaan akan kebutuhan gula kelapa murni semakin tinggi.

Pekerjaan sebagai perajin gula kelapa telah ada secara turun-temurun, tetapi berbagai keterbatasan yang dimiliki membuat perajin menjalankan usaha secara apa adanya serta kurang mempertimbangkan perkembangan jangka panjang. Kendalakendala pengembangan agroindustri adalah kemampuan dalam penggunaan teknologi, kualitas sumber daya manusia, cuaca yang tidak stabil dan infrastruktur pendukung industri yang masih terbatas, belum berkembangnya distribusi (Saputra dkk, 2012). Pemasaran menjadi ujung tombak dari sebuah usaha dan berpengaruh terhadap pendapatan produsen, sedangkan dilihat dari sistem pemasaran, sebagian besar perajin hanya menjual gula pada pengepul dan memiliki kemampuan tawar yang rendah. Hal ini merupakan salah satu faktor penyebab kurangnya efisiensi pemasaran dan perkembangan industri. Azhari menyatakan bahwa strategi pemasaran produk gula masih berjalan tradisional, yaitu pengetahuan informasi pasar diperoleh dari mulut ke mulut, pembuatan produk berdasarkan pesanan, jalur pemasaran yang dilakukan hanya dari produsen ke pengepul, dan produsen bertindak sebagai penerima harga (Azhari dkk., 2013).

Berdasarkan latar belakang dan adanya berbagai faktor yang dapat menjadi kendala dalam jalannya usaha, maka perlu disikapi dengan pengembangan strategi pemasaran 
agar usaha yang dijalakan oleh perajin dapat lebih berkembang, efisien dan meningkatkan pendapatan. Menurut (Wongkar dan Dumais, 2017), strategi pengembangan berpengaruh dalam menjaga daya saing atau eksistensi usaha, serta mengatasi masalah-masalah yang terjadi pada agroindustri. Gula semut merupakan produk turunan dari gula cetak yang memiliki prospek sangat bagus untuk dikembangkan karena hingga saat ini kebutuhan akan gula semut baik ekspor maupun dalam negeri belum terpenuhi (Evalia, 2015). Berdasarkan informasi yang diperoleh di lokasi penelitian, pengembangan usaha gula kelapa cetak kurang mendapatkan perhatian, oleh sebab itu dilakukan kajian terkait strategi pengembangan pemasaran produk gula kelapa cetak di Kabupaten Cilacap agar menjadi agroindustri yang dapat meningkatkan kesejahteraan perajin. Tujuan dari kajian ini adalah untuk mengidentifikasi faktor internal dan eksternal yang mempengaruhi pemasaran, dan menganalisis alternatif strategi pengembangan pemasaran gula kelapa. Kajian bermanfaat dalam menambah pengetahuan mengenai agroindustri gula kelapa, dan pelaku agroindustri diharapkan dapat mengembangkan sistem pemasaran yang semakin efisien.

Evaluasi faktor internal dan eksternal akan mempengaruhi pengembangan agroindustri gula, oleh sebab itu dilakukan identifikasi terhadap faktor-faktor strategis yang meliputi aspek kekuatan, kelemahan, peluang, dan ancaman. Analisis Matriks Evaluasi Faktor Internal - Analisis Matriks Faktor Eksternal (IFE-EFE) dilakukan untuk penilaian terhadap faktor-faktor dalam penentuan strategi pengembangan agroindustri (Evalia, 2015).

IFE-EFE adalah alat analisa yang menyajikan kondisi internal-eksternal suatu usaha untuk menentukan faktor kekuatan-kelemahan dan peluang-ancaman. Elemen yang terdapat pada faktor internal dan eksternal diperoleh dari hasil pengamatan lingkungan agroindustri gula kelapa di Kabupaten Cilacap. Langkah yang perlu dilakukan yaitu dengan memperhitungkan terlebih dahulu kesesuaian antara penilaian internal dan eksternal dari hasil kuesioner.
Kajian mengenai pengembangan agroindustri gula kelapa sebelumnya telah dilakukan, seperti yang telah ditunjukkan Irmawati dkk (2015) bahwa posisi industri gula semut berada pada sel $\mathrm{V}$ dengan strategi konsentrasi melalui integritas horizontal. Sama seperti penelitian Malik dkk (2018) yang menyatakan bahwa posisi usaha tani gula kelapa berada pada sel V. Berbagai latar belakang yang telah dijelaskan dalam kajian ini, dimungkinkan posisi industri gula kelapa di Kabupaten Cilacap berada pada sel IV yaitu fase stabil, dan alternatif strategi utama yang dapat diterapkan terdapat pada kuadran 1 yaitu strategi Strengths Opportunities. Hal ini memberikan indikasi bahwa peluang pengembangan strategi pemasaran produk gula berada dalam keadaan menguntungkan, selain memiliki kekuatan lebih besar dari pada kelemahan juga memiliki peluang lebih besar dari ancaman (Azhari dkk, 2013).

Manajemen strategi merupakan seni dan ilmu untuk memformulasikan, mengimplementasi, dan mengevaluasi keputusan lintas fungsi yang memungkinkan suatu usaha dapat mencapai tujuannya. Tujuan manajemen strategi adalah menciptakan hal baru dan berbeda untuk di masa yang akan datang (David, 2006). Setiap perusahaan atau usaha tentu memerlukan adanya strategi untuk mendukung manajemen yang baik. Strategi dapat didefinisikan sebagai rangkaian tindakan dengan tujuan untuk mencapai sasaran jangka panjang. Berdasarkan kajian yang telah dilakukan mengenai strategi pengembangan sistem agribisnis kelapa, formulasi efisiensi dan integrasi pada setiap subsistem harus dilakukan untuk meningkatkan pendapatan petani (Damanik, 2007).

Penyusunan alternatif strategi melalui beberapa tahap, mulai dari pengamatan, evaluasi hingga penentuan strategi yang tepat. Analisis SWOT adalah salah satu cara dalam penyusunan strategi dengan menganalisis faktor internal eksternal dari suatu usaha. Hal ini bertujuan agar usaha tersebut berjalan dan berkembang dengan efektif, efisien, dan berkelanjutan (Rangkuti, 2015). 
Kajian dilaksanakan di Kecamatan Jeruklegi dan Kawunganten Kabupaten Cilacap pada bulan Februari-April 2018. Lokasi kajian dipilih secara sengaja berdasarkan pertimbangan tertentu, yaitu merupakan daerah yang terdapat banyak agroindustri gula kelapa. Sumber data primer diperoleh langsung dari responden dengan teknik wawancara menggunakan bantuan kuesioner. Data sekunder diperoleh dari Dinas Perindustrian dan Koperasi Kabupaten Cilacap yang digunakan untuk menunjang data primer. Metode analisis yang digunakan dalam kajian ini antara lain: uji instrumen, analisis deskripsi, dan analisis SWOT.

\section{Uji Instrumen}

Uji instrumen terdiri dari uji validitas dan uji reliabilitas. Uji validitas dilakukan dengan tujuan untuk mendapatkan instrumen yang valid dan akurat. Tingkat validitas diperoleh dengan cara membandingkan probabilitas nilai $\mathrm{r}_{\mathrm{xy}}$ dengan $\mathrm{r}_{\text {tabel' }}$ rumus yang digunakan adalah sebagai berikut (Sanusi, 2011) :

$$
r x y=\frac{N \Sigma X Y-(\Sigma X)(\Sigma Y)}{\sqrt{\left\{\left(N^{2}-(\Sigma X)^{2}\right\}\left\{N \Sigma Y^{2}-(\Sigma Y)^{2}\right)\right\}}}
$$

Keterangan :

$$
\begin{aligned}
& \mathrm{N}=\text { Jumlah sampel } \\
& \mathrm{r} \quad=\text { Koefisien korelasi } \\
& \mathrm{X}=\text { Skor indikator yang akan diuji } \\
& \mathrm{Y} \quad=\text { Total skor indikator pada konsep } \\
& \text { yang sama }
\end{aligned}
$$

Uji reliabilitas dilakukan untuk mengetahui bahwa instrumen dapat dipercaya sebagai alat pengumpul data, dengan menghitung Cronbach Alpha. Adapun rumus yang dapat dituliskan sebagai berikut (Sanusi, 2011) :

$$
\mathrm{rsb}=\left(\frac{2 \mathrm{rpm}}{1+\mathrm{rpm}}\right)
$$

\section{Keterangan:}

$\mathrm{r}_{\mathrm{sb}} \quad=$ nilai reliabilitas instrumen

$\mathrm{r}_{\mathrm{pm}} \quad=$ nilai korelasi produk

Hasil uji reliabilitas ditentukan dengan cara membandingkan antara nilai cronbach alpha dengan nilai alfa pembanding. Apabila instrumen memiliki nilai cronbach alpha lebih besar dari alfa pembanding $(0,6)$ maka dinyatakan reliabel.

\section{Analisis Deskriptif}

Strategi pemasaran menitik beratkan pada identifikasi faktor-faktor internal dan eksternal dalam lingkungan usaha. Informasi yang diperoleh dianalisis dan dideskriptifkan secara terperinci, kemudian digunakan untuk menyusun strategi secara tepat agar menciptakan pemasaran yang lebih efisien sehingga dapat meningkatkan pengembangan usaha dan pendapatan perajin.

\section{Analisis SWOT}

Analisis SWOT dilakukan dengan melihat faktor-faktor internal dan eksternal yang dapat mempengaruhi pemasaran gula kelapa. Tabel IFAS/EFAS yang terdapat pada Tabel 1 digunakan untuk mengidentifikasi dan merumuskan faktor-faktor strategis dalam kerangka kekuatan, kelemahan, peluang, dan ancaman, selain itu juga untuk menentukan posisi usaha. Tahapan penentuan skor dalam tabel IFAS/EFAS menurut (Rangkuti, 2015) sebagai berikut.

a. Pembuatan faktor strategis lingkungan internal mencakup faktor kekuatan (strength) dan kelemahan (weakness), sedangkan faktor eksternal mencakup faktor peluang (opportunities) dan ancaman (threats).

b. Penentuan bobot faktor strategis dengan skala mulai dari 0,0 (tidak penting) sampai 1,0 (sangat penting).

c. Hitung rating untuk masing-masing faktor dengan memberikan skala 4,0 jika peluang besar hingga 1,0 jika peluang semakin kecil, dan pemberian nilai rating ancaman adalah kebalikannya.

d. Kalikan bobot dengan rating untuk memperoleh faktor pembobotan (skor).

e. Jumlahkan skor untuk memperoleh total skor pembobotan bagi perusahaan atau industri yang bersangkutan, dan total skor harus bernilai satu. 
Tabel 1.

IFAS dan EFAS

\begin{tabular}{|c|c|c|c|}
\hline Faktor Strategi & Bobot & Rating & Bobot $\mathrm{x}$ Rating \\
\hline \multicolumn{4}{|l|}{ Faktor Internal } \\
\hline \multicolumn{4}{|l|}{ Kekuatan } \\
\hline Ketersediaan bahan baku selalu ada & 0,15 & 3,99 & 0,58 \\
\hline Pengolahan dilakukan setiap hari & 0,14 & 3,93 & 0,56 \\
\hline Produk berkualitas super & 0,14 & 3,93 & 0,56 \\
\hline Cita rasa manis alami & 0,14 & 3,98 & 0,58 \\
\hline Biaya pemasaran rendah & 0,11 & 2,99 & 0,33 \\
\hline \multicolumn{4}{|l|}{ Kelemahan } \\
\hline Teknologi yang digunakan tradisional & 0,11 & 2,96 & 0,32 \\
\hline Keterbatasan modal usaha & 0,12 & 3,42 & 0,43 \\
\hline Informasi pasar kurang merata & 0,08 & 2,28 & 0,19 \\
\hline Total Skor Faktor Internal & 1,00 & & 3,54 \\
\hline \multicolumn{4}{|l|}{ Faktor Eksternal } \\
\hline \multicolumn{4}{|l|}{ Peluang } \\
\hline Harga gula dapat bersaing & 0,13 & 3,35 & 0,42 \\
\hline Reward dari pedagang langganan & 0,08 & 2,04 & 0,16 \\
\hline Pajak usaha rendah & 0,04 & 1,16 & 0,05 \\
\hline Lokasi penjualan mudah dijangkau & 0,12 & 3,18 & 0,38 \\
\hline Akses jalan cukup baik & 0,12 & 3,15 & 0,37 \\
\hline Armada distribusi sudah memadai & 0,12 & 3,11 & 0,36 \\
\hline Sistem pemasaran mudah & 0,10 & 2,76 & 0,29 \\
\hline \multicolumn{4}{|l|}{ Ancaman } \\
\hline Tidak rutin pengecekan dan pembinaan dari Dinas Kesehatan & 0,10 & 2,62 & 0,26 \\
\hline Belum terbentuk kelompok penderes & 0,10 & 2,65 & 0,26 \\
\hline Belum terbentuk koperasi usaha & 0,10 & 2,61 & 0,26 \\
\hline Total Skor Faktor Eksternal & 1,00 & & 2,81 \\
\hline
\end{tabular}

Sumber: Data Primer, 2018

Penentuan alternatif strategi pengembangan pemasaran gula kelapa di Kabupaten Cilacap dirumuskan berdasarkan data yang diperoleh dari tabel IFAS/EFAS. Berikut adalah kemungkinan alternatif strategi yang dapat diterapkan untuk meningkatkan efisiensi pemasaran (Rangkuti, 2015) :

a. Strategi Strengths Opportunities adalah strategi dengan menggunakan kekuatan yang dimiliki, untuk memanfaatkan peluang.

b. Strategi Strengths Threats adalah strategi dengan menggunakan kekuatan yang dimiliki, untuk menghindari atau mengurangi ancaman. c. Strategi Weaknesses Threats adalah strategi yang diarahkan untuk meminimalkan kelemahan untuk menghindari atau mengurangi ancaman.

d. Strategi Weaknesses Opportunities adalah strategi untuk memperbaiki kelemahan dengan memanfaatkan peluang.

\section{PEMBAHASAN}

Hasil pengujian instrumen berdasarkan validitas dan reliabilitas diperoleh bahwa terdapat 8 (delapan) indikator faktor internal dan 10 indikator pada faktor eksternal. 
Tabel 2.

Uji Validitas

\begin{tabular}{|c|c|}
\hline Indikator & $\mathbf{r}_{\text {hitung }}$ \\
\hline \multicolumn{2}{|l|}{ Faktor Internal } \\
\hline \multicolumn{2}{|l|}{ Kekuatan } \\
\hline Ketersediaan bahan baku selalu ada & 0,759 \\
\hline Pengolahan dilakukan setiap hari & 0,342 \\
\hline Produk berkualitas super & 0,580 \\
\hline Cita rasa manis alami & 0,759 \\
\hline Biaya pemasaran rendah & 0,407 \\
\hline \multicolumn{2}{|l|}{ Kelemahan } \\
\hline Teknologi yang digunakan tradisional & 0,325 \\
\hline Keterbatasan modal usaha & 0,517 \\
\hline Informasi pasar kurang merata & 0,629 \\
\hline \multicolumn{2}{|l|}{ Faktor Eksternal } \\
\hline \multicolumn{2}{|l|}{ Peluang } \\
\hline Harga gula dapat bersaing & 0,412 \\
\hline Reward dari pedagang langganan & 0,475 \\
\hline Pajak usaha rendah & 0,724 \\
\hline Lokasi penjualan mudah dijangkau & 0,503 \\
\hline Akses jalan cukup baik & 0,592 \\
\hline Armada distribusi sudah memadai & 0,584 \\
\hline Sistem pemasaran mudah & 0,363 \\
\hline \multicolumn{2}{|l|}{ Ancaman } \\
\hline Tidak rutin pengecekan dan pembinaan dari Dinas Kesehatan & 1,000 \\
\hline Belum terbentuk kelompok penderes atau usaha & 1,000 \\
\hline Belum terbentuk koperasi usaha & 1,000 \\
\hline
\end{tabular}

Sumber: Data Primer, 2018

Tabel 2 merupakan hasil uji validitas yang menunjukkan bahwa setiap pernyataan terdapat pada tingkat kepercayaan 95\%, dengan menggunakan $\mathrm{N}=47$ maka diketahui nilai $r$ tabel sebesar 0,287. Hasil tersebut dapat disimpulkan bahwa seluruh pernyataan bersifat valid karena memiliki nilai $\mathrm{r}$ hitung lebih besar dari nilai $\mathrm{r}$ tabel.
Uji reliabilitas bertujuan untuk mengetahui sejauh mana pengukuran dapat dipercaya. Hasil uji reliabilitas menunjukkan bahwa pernyataan-pernyataan yang digunakan dalam penentuan faktor kekuatan, kelemahan, peluang, dan ancaman sudah reliabel atau dapat dipercaya. Dilihat dari nilai cronbach alpha setiap variabel memiliki nilai yang lebih besar dari alfa pembanding $(0,6)$ (Tabel 3).

Tabel 3.

Uji Reliabilitas

\begin{tabular}{lllll}
\hline \multicolumn{1}{c}{ Variabel } & Jumlah Pernyataan & Cronbach alpha & Alfa Pembading & Keterangan \\
\hline Kekuatan & 5 & 0,664 & 0,6 & Reliabel \\
Kelemahan & 3 & 0,645 & 0,6 & Reliabel \\
Peluang & 7 & 0,781 & 0,6 & Reliabel \\
Ancaman & 3 & 1,000 & 0,6 & Reliabel \\
\hline
\end{tabular}

Sumber : Data Primer, 2018 


\section{Analisis SWOT Agroindustri Gula Kelapa}

Strategi pengembangan pemasaran agroindustri gula kelapa di Kabupaten Cilacap didasarkan pada identifikasi serta evaluasi faktor internal dan eksternal, sehingga dapat digunakan untuk menyusun strategi pengembangan dan menciptakan pemasaran yang lebih efisien. Didukung dengan pernyataan (Damanik, 2007) bahwa pengembangan agribisnis kelapa berperan penting dalam peningkatan pendapatan petani karena sebagai penyedia lapangan kerja.

Berdasarkan analisis SWOT yang dievaluasi menggunakan IFAS dan EFAS, agroindustri gula kelapa di Kabupaten Cilacap memiliki potensi besar untuk dikembangkan. Hasil tersebut didasarkan atas pertimbangan faktor kekuatan dan peluang yang lebih dominan dari pada kelemahan dan ancamannya.

\section{Kekuatan}

Dua faktor kekuatan yang menjadi kunci utama, di antaranya adalah cita rasa khas manis alami dan ketersediaan bahan baku air nira yang selalu ada. Cita rasa khas yang banyak diminati konsumen dan ketersediaan bahan baku nira sangat berpengaruh dalam mendorong peningkatan volume produksi serta perkembangan usaha. Didukung dengan proses pengolahan yang tidak terlalu lama, sehingga dapat dilakukan setiap hari. Hasil tersebut diperkuat dengan pernyataan Sugiyowati dkk (2014) bahwa ketersediaan bahan baku yang mudah dinyatakan sebagai faktor paling penting dalam pengembangan agroindustri gula aren. Produksi yang dapat dilakukan hampir setiap hari akan menjaga ketersediaan produk. Bukan hanya ketersediaan, tetapi gula kelapa di Kabupaten Cilacap ini rata-rata berkualitas super, hal tersebut didukung dengan kualitas air nira serta pengalaman yang dimiliki oleh perajin. Daya tarik akan produk ini dapat menjadi suatu kelebihan, selain itu rendahnya biaya setiap kegiatan pemasaran menjadi kekuatan dalam persaingan pasar.

\section{Kelemahan}

Teknologi merupakan salah satu hal penting dalam menjalankan sebuah usaha, penggunaan teknologi yang semakin modern akan menghasilkan produk yang semakin baik, tetapi penggunaan teknologi dalam kegiatan agroindustri gula kelapa di Kabupaten Cilacap masih sederhana yaitu belum menerapkan teknologi pengemasan. Pengemasan gula oleh perajin hanya sebatas menggunakan karung dalam bentuk curah. Hal ini dikarenakan sebagian besar perajin gula kelapa memiliki keterbatasan modal usaha khususnya dalam hal finansial. Kelemahan berupa keterbatasan modal akan sangat menghambat berkembangnya suatu usaha, karena menyebabkan pelaku usaha (perajin) cenderung bergantung pada pengepul. Hal serupa juga disebutkan (Umar, 2016) bahwa modal yang cukup sangat dibutuhkan dalam upaya peningkatan kualitas dan kuantitas produksi gula kelapa. Faktor kelemahan berupa keterbatasan modal tersebut menyebabkan perajin berada pada posisi tawar yang lemah. Lemahnya posisi tawar ini juga didukung dengan aksesibilitas informasi pasar yang kurang merata khususnya pada pihak perajin mengenai harga pasar.

\section{Peluang}

Harga gula kelapa di Kabupaten Cilacap sudah dikatakan dapat bersaing dengan daerah lain dan merupakan faktor peluang yang dapat dimanfaatkan oleh pelaku usaha untuk meningkatkan penjualan. Azhari dkk (2016) menyatakan bahwa suatu industri yang memanfaatkan peluang dengan baik akan mampu bertahan dalam persaingan serta mendorong adanya pengembangan. Pengembangan usaha juga dipengaruhi oleh bahan baku dan biaya pemasaran serta pajak usaha yang murah. Hal ini dibuktikan dengan luasnya penyebaran area penjualan bahkan hingga luar Pulau Jawa.

Faktor pemasaran seperti memberikan reward pada relasi usaha serta menjalin hubungan yang semakin baik antara penjual dan pembeli dapat diterapkan untuk meningkatkan peluang. Selain itu, kemudahan 
pemasaran seperti penggunaan sistem online juga menunjang jalannya usaha. Didukung dengan mudahnya jangkauan lokasi penjualan, baik lokasi dari perajin ke pengepul maupun hingga konsumen akhir. Hal ini sangat berpengaruh dalam pendistribusian produk dan dapat menghemat biaya transportasi. Terlebih saat ini armada distribusi para pelaku usaha serta akses jalan sudah cukup memadai. Kemudahan sistem pemasaran menjadikan peluang untuk pengembangan pemasaran dan pengoptimalan usaha.

\section{Ancaman}

Hampir seluruh perajin gula kelapa di Kabupaten Cilacap belum mendapatkan pembinaan secara rutin dari pihak pemerintah terkait jalannya usaha, padahal fasilitas tersebut sangat erat hubungannya dengan perkembangan usaha yang dijalankan. Isnaini dkk. (2011) juga menyatakan bahwa pembinaan intensif bagi pengusaha gula sangat mempengaruhi dalam pengembangan usahanya. Jalannya agroindustri gula kelapa di wilayah ini juga belum ditunjang dengan adanya kelompok penderes, di mana faktor tersebut memiliki pengaruhnya paling besar dalam perkembangan usaha karena menyebabkan perajin menjalankan usahanya secara individu dan tidak memperoleh bantuan modal usaha dari lembaga atau pemerintah setempat. Hal lain yang juga menghambat berkembangnya usaha gula kelapa di wilayah ini adalah belum terbentuknya koperasi. Peran koperasi memiliki pengaruh besar karena dapat sebagai penyetara harga dan mendukung perkembangan usaha. Pernyataan tersebut didukung oleh Syahza (2012) bahwa peran koperasi sangat penting dalam pengembangan usaha dan kesejahteraan masyarakat.

\section{Potensi Pengembangan Agroindustri Gula Kelapa}

Hasil evaluasi yang telah dilakukan menunjukkan posisi usaha gula kelapa di Kabupaten Cilacap terdapat pada sel IV yaitu fase stabil. Artinya fase ini ada dalam keadaan normal dan dapat mempertahankan strategi yang telah dijalankan, tetapi untuk mengembangkannya pelaku usaha perlu memaksimalkan kekuatan dengan memanfaatkan peluang. Hal ini dirumuskan sebagai strategi yang sesuai dalam pengembangan pemasaran.

Alternatif strategi paling menonjol yang dapat diterapkan adalah strategi S-O (Strenghts Opportunities), yaitu memanfaatkan kekuatan untuk meningkatkan peluang. Didasarkan hasil kajian Karmiati dkk (2016) yang menyebutkan bahwa penggunaan alternatif strategi untuk mendukung pengembangan agroindustri gula tumbu adalah strategi S-O yaitu mendukung pertumbuhan agresif.

Pengembangan usaha gula kelapa tidak hanya sebatas memanfaatkan kekuatan dan peluang saja, tetapi kelemahan dan ancaman juga perlu diatasi dengan strategi W-T, selain itu keberhasilan dalam pengembangan pemasaran tentu ditunjang dengan alternatif strategi lain yang meliputi strategi W-O dan $\mathrm{S}-\mathrm{T}$. Analisis penentuan strategi dengan model matriks SWOT yang menggunakan data dari Tabel IFAS dan EFAS terdapat pada tabel 4.

\section{Strategi (S-O)}

Berbagai alternatif strategi yang dapat diterapkan dalam proses pengembangan agroindustri gula kelapa di Kabupaten Cilacap didasarkan pada kekuatan dan pemanfaatan peluang yang ada. Hal tersebut dapat mendorong adanya optimalisasi kapasitas produksi, baik dari segi kuantitas dan kualitas, terlebih lagi Cilacap merupakan daerah sentra tanaman kelapa sehingga bahan baku yang murah mudah didapat. Bukan hanya optimalisasi kapasitas produksi, tetapi meningkatkan kegiatan pemasaran dan perluasan area penjualan juga dapat terus dilakukan, mengingat permintaan konsumen yang tinggi. Di sisi lain pentingnya kegiatan promosi yang baik bertujuan sebagai ajang untuk meningkatkan permintaan akan produk (Damanik, 2007). Permintaan produk yang meningkat tidak menutup kemungkinan bahwa area penjualan juga semakin luas, perluasan area ini salah satunya dapat dilakukan dengan cara memanfaatkan teknologi informasi berupa internet (Malik dkk., 2018). 
Tabel 4

Penentuan Strategi Dengan Model Matriks SWOT

\begin{tabular}{|c|c|c|}
\hline $\begin{array}{r}\text { INTERNAL } \\
\text { FAKTOR }\end{array}$ & $\begin{array}{l}\text { KEKUATAN } \\
\text { - Ketersediaan bahan baku } \\
\text { selalu ada } \\
\text { - Pengolahan dilakukan } \\
\text { setiap hari } \\
\text { - Produk berkualitas super } \\
\text { - Cita rasa manis alami } \\
\text { - Biaya pemasaran rendah }\end{array}$ & $\begin{array}{l}\text { KELEMAHAN } \\
\text { - Teknologi masih } \\
\text { tradisional } \\
\text { - Keterbatasan modal usaha } \\
\text { sehingga bergantung } \\
\text { pada pengepul } \\
\text { - Informasi pasar kurang } \\
\text { merata }\end{array}$ \\
\hline $\begin{array}{l}\text { PELUANG } \\
\text { - Harga gula dapat bersaing } \\
\text { - Reward dari pedagang langganan } \\
\text { - Pajak usaha rendah } \\
\text { - Lokasi penjualan mudah dijangkau } \\
\text { - Akses jalan cukup baik } \\
\text { - Armada distribusi memadai } \\
\text { - Sistem pemasaran mudah }\end{array}$ & $\begin{array}{l}\text { SO STRATEGI } \\
\text { - Optimalisasi kapasitas } \\
\text { produksi } \\
\text { - Memperluas area penjualan } \\
\text { - Meningkatkan kegiatan } \\
\text { promosi }\end{array}$ & $\begin{array}{l}\text { WO STRATEGI } \\
\text { - Meningkatkan } \\
\text { penggunaan teknologi } \\
\text { alat produksi } \\
\text { - Meningkatkan efisiensi } \\
\text { pemasaran } \\
\text { - Menambah pengetahuan } \\
\text { mengenai harga pasar }\end{array}$ \\
\hline $\begin{array}{l}\text { ANCAMAN } \\
\text { - Tidak rutin adanya pengecekan dan } \\
\text { pembinaan dari Dinas Kesehatan } \\
\text { - Belum terbentuk kelompok penderes } \\
\text { - Belum adanya koperasi usaha }\end{array}$ & $\begin{array}{l}\text { ST STRATEGI } \\
\text { - Mempertahankan produk } \\
\text { berkualitas } \\
\text { - Pemilihan pengurus untuk } \\
\text { membentuk kelompok } \\
\text { penderes } \\
\text { - Menjalin kerja sama } \\
\text { antardesa } \\
\end{array}$ & $\begin{array}{l}\text { WT STRATEGI } \\
\text { - Meningkatkan kebersihan } \\
\text { saat produksi } \\
\text { - Meminjam uang pada } \\
\text { koperasi di daerah lain } \\
\text { untuk modal usaha } \\
\text { - Membangun pusat } \\
\text { layanan informasi } \\
\end{array}$ \\
\hline
\end{tabular}

Sumber : Data Primer, 2018

\section{Strategi (S-T)}

Produk berkualitas baik sangat berpengaruh pada penjualan, oleh sebab itu perajin perlu mempertahankan dan meningkatkan kualitas gula kelapa yang diproduksi. Peningkatan kualitas produk juga bertujuan untuk terbentuknya inovasi serta peningkatan kepercayaan konsumen (Malik dkk 2018). Hal ini dapat dilakukan dengan cara menggunakan bahan penolong yang tidak berlebihan serta semakin menjaga kebersihan bahan baku maupun alat pengolahan. Tidak hanya kualitas produk yang perlu dipertahankan, tetapi pembentukan kelompok penderes baik dalam desa maupun bekerja sama antardesa juga perlu dilakukan sehingga usaha lebih terorganisir dan dapat meningkatkan efisiensi pemasaran serta perkembangan usaha yang lebih baik.

\section{Strategi (W-O)}

Peningkatan efisiensi pemasaran menjadikan setiap lembaga pemasar atau pelaku usaha saling menguntungkan.Strategi ini dapat dilakukan dengan cara tidak bergantungnya perajin pada pengepul, sehingga posisi tawar petani dapat lebih kuat. Hal lain yang perlu diterapkan yaitu menambah wawasan dan pengetahuan mengenai informasi pasar khususnya harga. Saat ini sistem pemasaran sudah semakin mudah, media sosial dapat dijadikan peluang besar yang harus dimanfaatkan untuk mencari informasi pasar. Peningkatan informasi pasar juga dapat memperkuat posisi tawar petani (Damanik, 2007). Alternatif strategi lain yang mendorong perkembangan agroindustri gula kelapa adalah peningkatan penggunaan teknologi, salah satunya yaitu teknologi pengemasan yang lebih rapi akan meningkatkan kualitas produk sehingga harga jual lebih tinggi. Strategi serupa 
dalam meningkatkan penggunaan teknologi adalah kemasan yang menarik agar respons konsumen lebih tinggi (Malik dkk., 2018).

\section{Strategi (W-T)}

Kepuasan

konsumen dijadikan landasan untuk mewujudkan perkembangan agroindustri gula kelapa yang lebih baik. Oleh karena itu, perlu dilakukannya peningkatan kebersihan saat produksi, baik berupa alat, ruang produksi maupun bahan baku yang digunakan. Seperti yang telah dijelaskan sebelumnya bahwa faktor keterbatasan modal merupakan kelemahan yang sangat mempengaruhi pengembangan usaha, dan perajin cenderung menjalankan usahanya dengan bergantung pada pengepul. Belum terbentuknya koperasi di wilayah ini, maka sebaiknya pelaku usaha meminjam uang pada koperasi di daerah lain untuk mendukung usahanya. Malik dkk (2018) menyatakan bahwa strategi yang dapat diterapkan dalam pengembangan usaha tani gula kelapa adalah meningkatkan daya saing melalui koperasi atau asosiasi untuk pemasaran bersama. Alternatif strategi lain yang dapat diterapkan yaitu membangun pusat layanan informasi yang didukung oleh penyuluh atau pemerintah setempat, sehingga para perajin gula kelapa dapat lebih mudah dalam memperoleh berbagai informasi yang dibutuhkan. Hal serupa disebutkan oleh Umar (2016) bahwa alternatif strategi yang diterapkan dalam pengembangan kelompok usaha gula kelapa adalah menyediakan pusat layanan serta sumber daya eksistensi yang lapang, sehingga dapat menjadi media dalam memberikan informasi bagi perajin.

\section{SIMPULAN}

Pengembangan agroindustri gula kelapa di Kabupaten Cilacap dipengaruhi oleh faktorfaktor internal, antara lain adalah ketersediaan bahan baku selalu ada, pengolahan dilakukan setiap hari, produk berkualitas super, cita rasa manis alami, teknologi masih tradisional, keterbatasan modal usaha sehingga bergantung pada pengepul, dan informasi pasar kurang merata. Faktor eksternal meliputi harga gula dapat bersaing, reward dari pedagang langganan, pajak usaha rendah, lokasi penjualan mudah dijangkau, akses jalan cukup baik, armada distribusi memadai, sistem pemasaran mudah, tidak rutin adanya pengecekan dan pembinaan dari Dinas Kesehatan, belum terbentuk kelompok penderes, dan koperasi usaha.

Posisi industri terdapat pada sel IV yaitu fase stabil dan alternatif strategi utama yang dapat diterapkan adalah strategi SO yang terdiri dari optimalisasi kapasitas produksi, memperluas area penjualan, dan meningkatkan kegiatan promosi. Alternatif strategi lain yang dapat mendukung pengembangan agroindustri adalah meningkatkan penggunaan teknologi alat produksi, meningkatkan efisiensi pemasaran, menambah pengetahuan mengenai harga pasar, mempertahankan produk berkualitas, pemilihan pengurus untuk membentuk kelompok penderes, menjalin kerja sama antardesa, meningkatkan kebersihan saat produksi, meminjam uang pada koperasi di daerah lain untuk modal usaha, dan membangun pusat layanan informasi.

Perajin gula kelapa dapat menerapkan berbagai alternatif strategi pemasaran yang telah dipaparkan agar pemasaran gula kelapa semakin efisien serta menunjang pengembangan usaha yang lebih baik. Diperlukannya pembentukan kelompok penderes, agar posisi perajin bisa lebih kuat, selain itu kuatnya peran pemerintah dalam memfasilitasi pengembangan usaha agroindustri gula kelapa di Kabupaten Cilacap juga sangat diperlukan.

\section{DAFTAR PUSTAKA}

Azhari, M.H, M. R. Yantu, danD.N. Asih. 2013 Pengembangan Strategi Pemasaran Produk Gula Tapo (Studi Kasus Di Desa Ambesia Kecamatan Tomini Kabupaten Parigi Moutong),Jurnal Agrotekbis, 1: 81-92.

Azhari, S. R., Kartikowati, S. dan Indrawati, H. 2016 Strategi Pengembangan Usaha Gula Aren di Desa Rambah Tengah Barat Kecamatan Rambah Kabupaten Rokan Hulu, Jurnal Online Mahasiswa Fakultas Keguruan 
dan Ilmu Pendidikan Universitas Riau. Riau University, 3(2): 1-14.

Damanik, S. 2007 Strategi Pengembangan Agribisnis Kelapa (Cocos nucifera) untuk Meningkatkan Pendapatan Petani di Kabupaten Indragiri Hilir, Riau, Perspektif, 6(2): 94-104.

Evalia, N. A. 2015 Strategi Pengembangan Agroindustri Gula Semut Aren, Jurnal Manajemen dan Agribisnis, 12(1): 57-67. doi: 10.17358/JMA.12.1.57.

Irmawati, H. Syam, dan Jamaluddin. 2015 Analisis Kelayakan Finansial dan Strategi Pengembangan Usaha Industri Rumahan Gula Semut (Palm Sugar) dari Nira Nipah di Kelurahan Pallantikang, Jurnal Pendidikan teknologi Pertanian, 1: 76-94.

Isnaini, R., S. Afifuddin, dan S. Lubis. 2011 Strategi Pengembangan Usaha Gula Aren di Kabupaten Aceh Tenggara, Jurnal Agribisnis Sumatera Utara, (2):55-65.

Karmiati, Vitus Dwi Yunianto, B. W. H. E. Prasetiyono. 2016 Strategi Pengembangan Agro Industri Gula Tumbu Di Kabupaten Kudus, Jurnal Litbang Provinsi Jawa Tengah, 14(4): 25-34.
Malik, W. A., Ferichani, M,dan Widiyanti, E. 2018 Strategi Pengembangan Usahatani Gula Kelapa di Kecamatan Puring Kabupaten Kebumen, SEPA, 14(2): 105-113.

Rangkuti, F. 2015 Teknik Membedah Kasus Bisnis Analisis SWOT. Jakarta: Gramedia Pustaka Utama.

Sanusi, A. 2011 Metode Penelitian Bisnis. Jakarta: Penerbit Salemba Empat.

Saputra. E, L Fitriana, dan E. Bahar 2012 Strategi Pengembangan Usaha Gula Aren Di Desa Rambah Tengah Barat Kecamatan Rambah Kabupaten Rokan Hulu, Penelitian Sungkai, 1(1).

Sugiyowati, L, Karno, dan Ekowati, T. 2014 StrategiPengembangan Agroindustri Gula Aren Di Kabupaten Kendal. Jurnal Agromedia, 33(1)

Syahza, A. 2012 Ekonomi pembangunan: teori dan kajian empirik pembangunan pedesaan. Pekanbaru: UR PRESS.

Umar, Z. A. 2016 The Development Strategy of Coconut Sugar Industry, The International Journal of Engineering and Science, 5(3): 58-66.

Wongkar. N, J. N. K. Dumais, dan T. M. Katiandagho. 2017 Strategi Pengembangan Agroindustri Gula Aren Di Desa Tondei 1, Agri-SosioEkonomi, 13: 215-226. 